\title{
LOAD FREQUENCY CONTROL OF A TWO AREA HYBRID SYSTEM CONSISTING OF A GRID CONNECTED PV SYSTEM AND THERMAL GENERATOR
}

\author{
Feba Thamar Tomy ${ }^{1}$, R.Prakash ${ }^{2}$
}

\begin{abstract}
Load frequency control of the hybrid system consisting photovoltaic system and thermal generator is performed in this paper. In this paper Maximum Power Point Tracking is performed in photovoltaic using modified hill climbing algorithm. Modified hill climbing is performed by combining fuzzy logic with hill climbing algorithm. The converter used is Boost converter. DC output obtained is converted to AC output by using single phase inverter. Grid connection is performed by using sinusoidal pulse width modulation. Transfer function model of the whole system is created. Transfer function model of the thermal generator is interfaced with the photovoltaic system to create two area systems. Load frequency controls of this two area system are performed. The simulation of the entire system is performed in the MATLAB SIMULINK.
\end{abstract}

Keywords: -PhotoVoltaic (PV), Maximum Power Point Tracking (MPPT), Hill Climbing, Load Frequency Control (LFC), Area Controlled Error (ACE), Sinusoidal Pulse Width Modulation (SPWM)

\section{INTRODUCTION}

The energy which is harvested from the natural resources like sunlight, wind, tides, geothermal heat etc. is called Renewable Energy.[1] As these resources can be naturally replenished, for all practical purposes, these can be considered to be limitless unlike the tapering conventional fossil fuels. The global energy crunch has provided a renewed impulsion to the growth and development of Clean and Renewable Energy sources. Clean Development Mechanisms (CDMs) are being adopted by organizations all across the globe.[1] Another advantage of utilizing renewable resources over conventional methods is the significant reduction in the level of pollution associated. The cost of conventional energy is rising and solar energy has emerged to be a promising alternative.[2] They are abundant, pollution free, distributed throughout the earth and recyclable. PV arrays consist of parallel and series combination of PV cells that are used to generate electrical power depending upon the atmospheric specifies (e.g. solar insolation and temperature).

Solar technologies are broadly qualified as either passive or active depending on the way they catch, change over and distribute sunlight. Active solar proficiencies use photovoltaic arrays, pumps, and fans to convert sunlight into executable outputs.[2] Passive solar techniques include selecting materials with favorable thermal attributes, and citing the position of a building to the Sun. The standalone PV Systems have been used for solar street lighting, home lighting system, SPV water pumping system. A hybrid system installed with a backup system of thermal generator can be used in remote military installations, health centers and tourist bungalows. In grid connected system the major part of the load during the day is supplied by the PV array and then from the grid when the sunlight is not sufficient. Solar energy can be used in two different ways. [2],[3] The captured heat can be used as solar thermal energy with important applications in space heating. On the other hand it can also be converted into the most useful form of energy, the electrical energy. The latter can be achieved with the use of solar photovoltaic cell. The efficiency of solar photovoltaic cells with single crystal silicon is about 13 $\%-17 \%$.[1],[3] High efficiency cells with concentrators are being manufactured which can operate with low sunlight intensities. India has an expanding solar energy sector namely 9 solar cell manufactures, $22 \mathrm{PV}$ module manufactures, and 50 PV systems manufacturers. Therefore, technology resources exist in country and a growing market would lead to job growth in country.

\section{GRID CONNECTED SOLAR SYSTEM}

The PV panel has low conversion efficiency. In order to improve the tracking efficiency of the PV system we had to use the MPPT algorithm. The MPPT will regulate the input side. By using the MPPT algorithm the output voltage will remains constant irrespective of the external conditions. The output of the MPPT is DC voltage. To perform the grid connection we have to convert it to AC. Here it uses the single phase inverter to convert the DC to AC. SPWM technique is used to perform the grid connection 


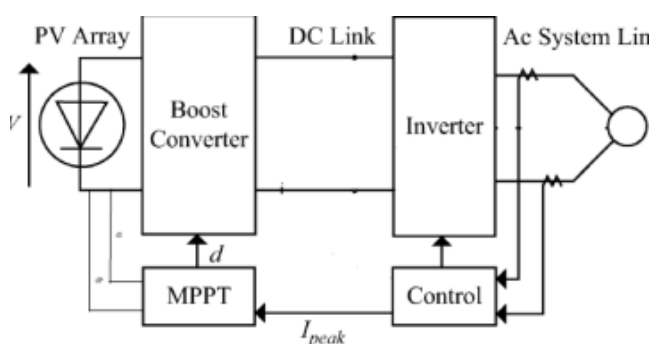

Fig 1 Block Diagram of PV System

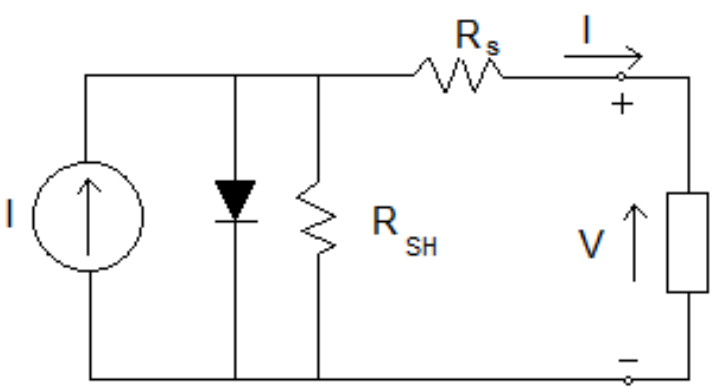

Fig 2 Equivalent circuit of solar cell

\subsection{Solar Cell Panel}

Solar cell panel works on the basis of Photo voltaic effect.A solar cell consists of a semi-conductor where the front and reverse side have been processed (doped) so that the front side normally has a surplus of free electrons while the reverse side has a deficit.[3] Bound electrons in the solar cell can absorb a photon and thereby become mobile. Most of them will be caught by the field in the interface and transported to the front side of the cells.[3] If the front- and reverse side are connected with an electrical circuit, the electron can do useful work in a light bulb, electrical motor, and computer. Solar cells give an output voltage of approximately $0.3-0.6 \mathrm{~V}$, depending on the technology[3][4].

The equivalent circuit of a solar cell is as shown in the figure 2 . Solar panel can be modeled with the help of equation 1 and 2 .

$$
\begin{aligned}
& I=I_{l}-I_{0}\left(e^{\frac{q\left(V-I R_{S}\right)}{A k T}}-1\right) \\
& -\frac{\mathrm{V}-\mathrm{IR}_{\mathrm{S}}}{\mathrm{R}_{\mathrm{SH}}} \\
& \mathrm{I}_{1}=\left(\frac{\lambda}{1000}\right)\left[\mathrm{I}_{\mathrm{SC}}\right. \\
& +\mathrm{k}_{1} \text { ( } \mathrm{T} \\
& -25) \text { ] }
\end{aligned}
$$

$\mathrm{I}_{1}=$ Photo current

$\mathrm{I}_{0}=$ Dark saturation current

$\mathrm{I}_{\mathrm{SC}}=$ Short circuit current

$k=$ Boltzmann constant

$\mathrm{v}=$ Solar cell output voltage

$\mathrm{q}=$ Charge of electron

$\mathrm{T}=$ Temperature in Kelvin

$\mathrm{A}=$ Diode quality factor

$\Lambda=$ Irradiance

The power generated by the PV cell is depend up on the temperature and the irradiance.[3][4] It is directly proportional to the irradiance and inversely proportional to temperature. This can be shown in the figure 3,4

\subsection{Maximum Power Point Tracking}

Maximum Power Point Tracking (MPPT) is a method used to harness the maximum power from a solar panel. PV panel arrays are nonlinear in nature. [4][5][10]It depends up on factors like temperature and irradiance. MPPT will provide input voltage regulation. The MPPT algorithm is implemented on PV panel to improve efficiency of PV panel otherwise only less than $50 \%$

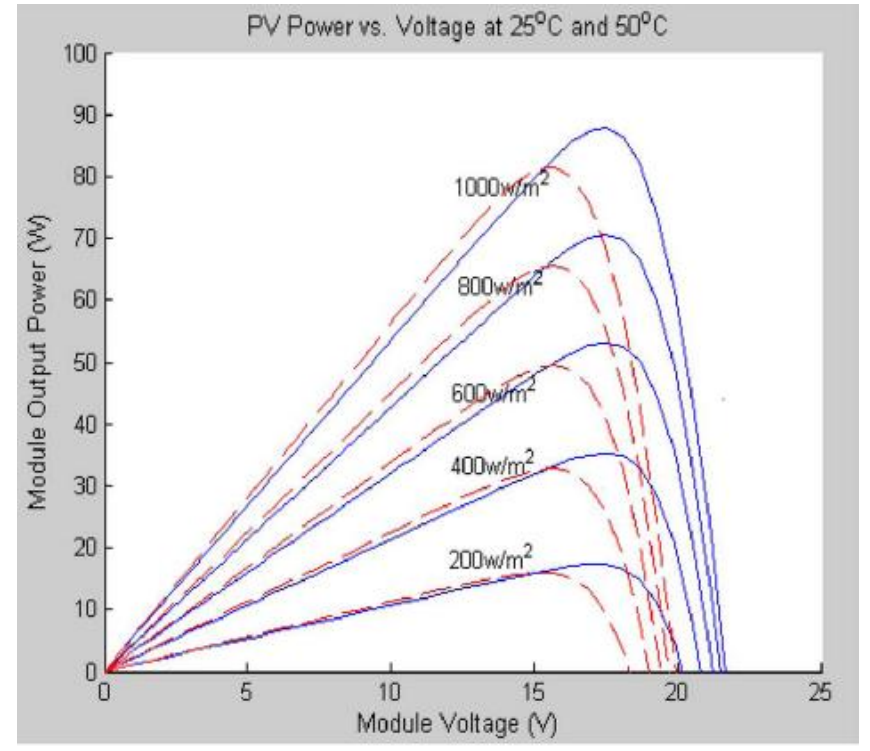

Fig 3 Temperature and irradiance effect on $\mathrm{P}-\mathrm{V}$ characteristics

Where

$\mathrm{I}=$ Solar cell output current 


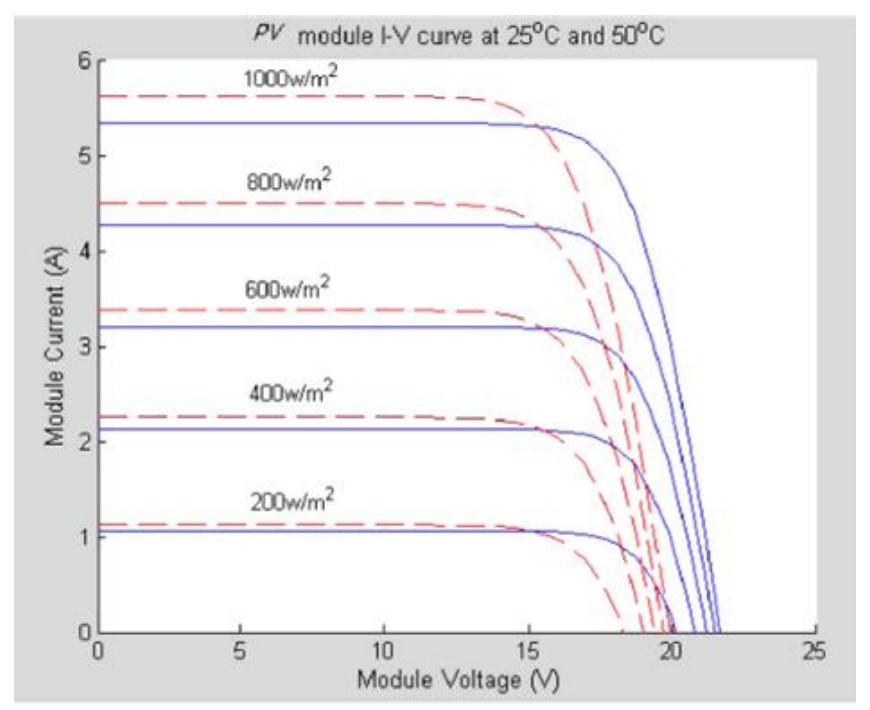

Fig 4 Temperature and irradiance effect on I-V characteristics

of solar energy incident is converted to electrical energy. According to maximum power transfer theorem,the power output of a circuit is maximum when the Thevenin impedance of the circuit (source impedance) matches with the load impedance.[4][5] Hence our problem of tracking the maximum power point reduces to an impedance matching problem. By varying the duty cycle of the DC-DC converter we can able to match the source impedance with load impedance. The method is based on the Power versus Voltage characteristic of a solar panel shown in Fig. 3. The point on the curve where the power is maximized is called the Maximum Power Point (MPP) of the solar panel. By inserting a DC/DC converter between the solar panel and the load, the voltage of the solar panel can be controlled to be $V_{M P P}$ and thus deliver maximum power to the load. Another advantage of this technique is that, if an up/down converter is used for the maximum power point tracker; power can then be delivered to loads with higher or lower voltage than the solar panel, enabling new applications for the same solar panel.

There are different techniques used to track the maximum power point. Few of the most popular techniques are,

a) Open Voltage method:-

b) Fractional Short Circuit Current methods

c) Fractional Open Circuit Voltage method

d) Perturb and Observe methods

e) Incremental Conductance method

f) Neural networks method

g) Fuzzy logic method

Here in this method fuzzy logic control is combined with the hill climbing method to eliminate the disadvantage of both the method. Fuzzy logic controller will take care of the dynamic characteristic[4],[5],[10] of the PV panel while hill climbing algorithm will take care of the static characteristic of the PV panel, that is fuzzy logic controller will used in the changing weather condition while hill climbing algorithm used in constant weather condition. This method will improve the tracking speed compare to the conventional methods of fuzzy logic and hill climbing method.

In this proposed method change in power and change incurrent are taken as the input to the fuzzy logic controller while change in duty cycle is taken as the output of the fuzzy logic controller. The output thus obtained is given as the firing pulse of the boost converter and the boost converter will regulate the voltage.

$$
\begin{gathered}
\Delta \mathrm{P}=\mathrm{P}(\mathrm{K})-\mathrm{P}(\mathrm{K}-1) \\
\Delta \mathrm{I}=\mathrm{I}(\mathrm{K})-\mathrm{I}(\mathrm{K}-1) \\
\Delta \mathrm{D}=\mathrm{D}(\mathrm{K})-\mathrm{D}(\mathrm{K}-1)
\end{gathered}
$$

Where

$\Delta \mathrm{P}=$ Change in power

$\Delta \mathrm{I}=$ Change in current

$\Delta \mathrm{D}=$ Change in duty cycle

Inputs change in power and current and the output change in duty cycle are divided into four fuzzy subsets Negative Big (NB), Negative small (NS), Positive Big (PB), and Positive Small (PS) as shown in the figure,5,6. The fuzzy rule base are shown in the table1 as shown below. Mamdani's method with Max-Min is used for the Fuzzy combination.[4][5] Defuzzification is the last stage of fuzzy controller. Center of Area Algorithm is used here for Defuzzification.

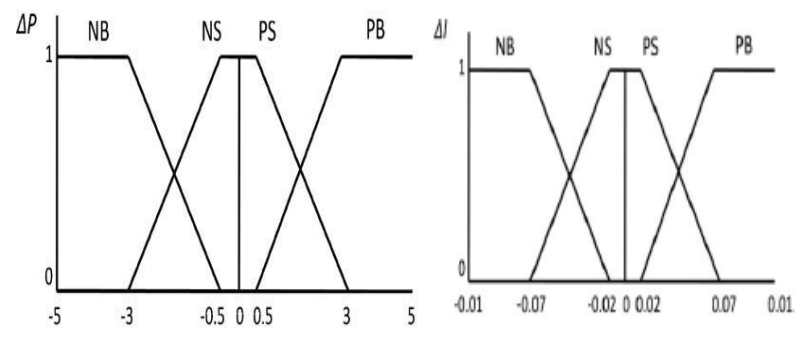

Fig. 5. Membership function for inputs $\Delta \mathrm{P}$ and $\Delta \mathrm{I}$

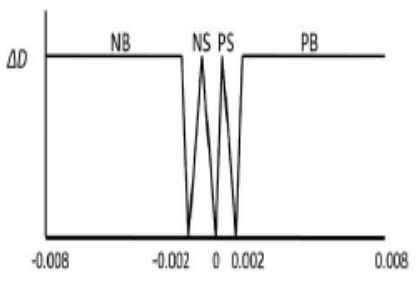

Fig. 6. Membership function $\Delta \mathrm{D}$

Table 1 Fuzzy rule base 


\begin{tabular}{|c|c|c|c|c|}
\hline$\Delta \mathrm{I}$ & \multirow{2}{*}{ PB } & \multirow{2}{*}{ PS } & \multirow{2}{*}{ NB } & \multirow{2}{*}{ NS } \\
\hline$\Delta \mathrm{P}$ & & & & \\
\hline PB & PB & PB & NB & NB \\
\hline PS & PS & PS & NS & NS \\
\hline NB & NB & NB & PB & PB \\
\hline NS & NS & NS & PS & PS \\
\hline
\end{tabular}

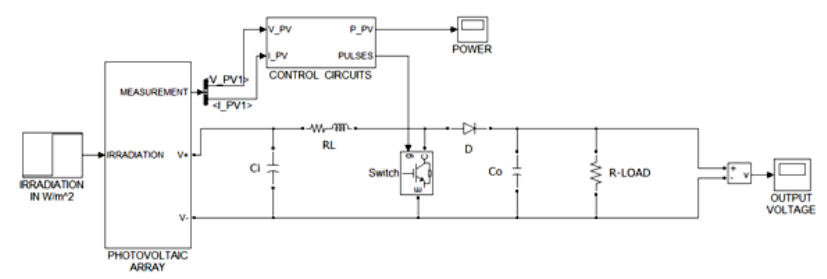

Fig 7 Boost Converter with MPPT

Here in this paper uses the Boost converter as the DC-DC converter as shown in the figure 7. Boost Converter is a DCDC converter for which output voltage is greater than input voltage. Thus the average voltage across the load is greater than the input voltage and is determined with help of the duty cycle of the gate pulse to the MOSFET switch.[4] Boost converter has two modes of operation. ON state mode of operation and OFF state mode of operation circuit diagram of this is shown in the figure 8,9 .

ON STATE $\left\{\begin{array}{c}L \frac{d i_{1}}{d t}=V_{P V} \\ C \frac{d V_{0}}{d t}+\frac{V_{0}}{R}=0\end{array}\right.$

OFF STATE $\left\{\begin{array}{c}L \frac{d i_{l}}{d t}+v_{0}=V_{P V} \\ i_{l}-C \frac{d v_{0}}{d t}+\frac{V_{0}}{R}=0\end{array}\right.$

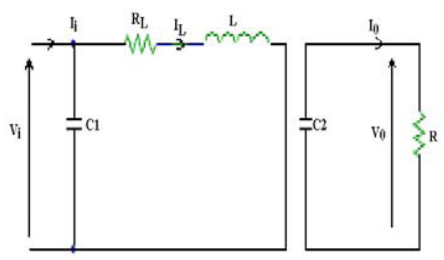

Fig. 8. ON state operation

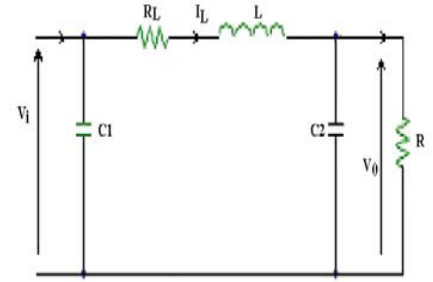

Fig. 9. OFF state operation

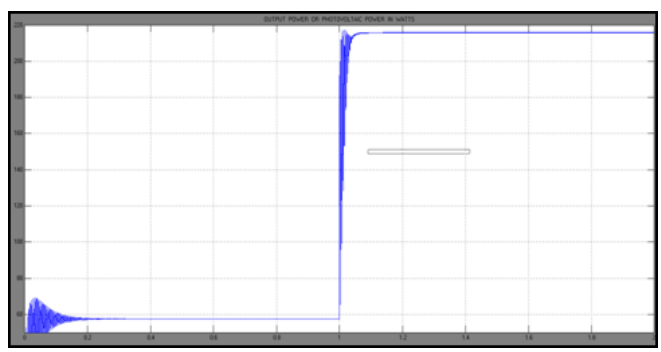

Fig. 10. Output power

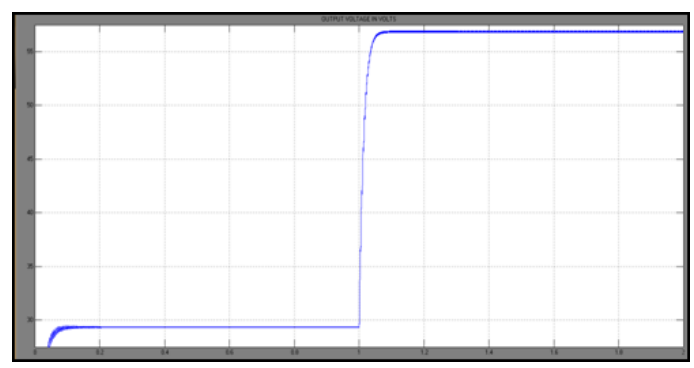

Fig.11. Output voltage

\subsection{Grid Connection}

To perform the grid connection we have to convert the DC output obtained from the MPPT to AC and have to made the voltage same as that of the grid voltage. To convert the DC voltage to $\mathrm{AC}$ we use an inverter as shown in the figure 12 . To maintain the voltage constant we have to use the SPWM which is shown in the figure 13. [9]The switches $S_{1}$ and $S_{2}$ will conduct at one instant to produce the positive half cycle. At the next instant $S_{3}$ and $S_{4}$ will conduct to perform the negative half cycle as shown in the figure 12. By using this inverter we will get a single phase $\mathrm{AC}$ so it is called as single phase inverter.

With the help of the SPWM technique we can able to produce the gate signals for the switches. Here the sinusoidal wave generated is multiplied with the $\mathrm{V}_{\text {peak }}$ and $\mathrm{I}_{\text {peak. }}$.The voltage reference is then compared with the $\mathrm{V}_{\mathrm{ac}}$. Current reference and voltage reference is added up. The signal thus obtained is compared with the $\mathrm{I}_{\mathrm{ac}}$.[9] This is then compared with the triangular signal to form the gate signal for the Inverter. Output of grid connected system is shown in figure 14 


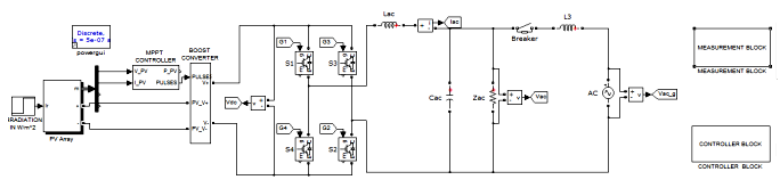

Fig 12 Inverter

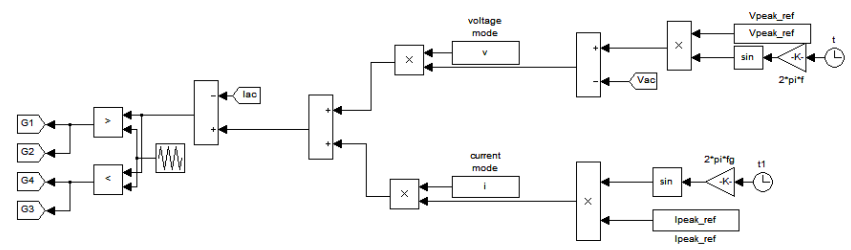

Fig 13 SPWM controller

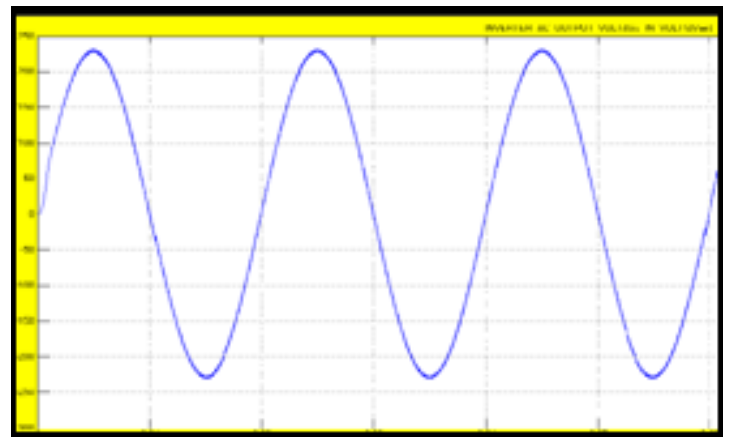

Fig. 14.Output of Grid connected system

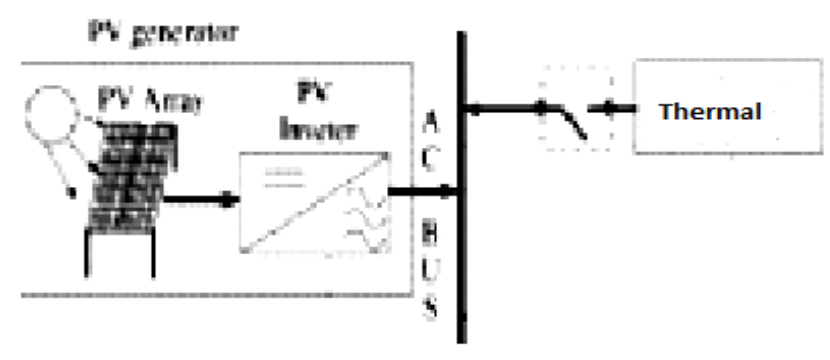

Fig 15 Overall system

\section{LFC OF TWO AREA SYSTEM CONSIST OF PV SYSTEM AND THERMAL GENERATOR}

Changes in the power system load affect mainly the system frequency and real power.[8] The load frequency control mainly deals with the control of the system frequency and real power.

Load frequency control is the basis of many advanced concepts of the large scale control of the power system. The reasons for keeping a strict limit on the system frequency variation were
- The speed of the alternating current motors depends on the frequency of the power supply.

- If the normal frequency id 50 Hertz and the system frequency falls below $47.5 \mathrm{Hertz}$ or goes up above 52.5 Hertz then the blades of the turbine are likely to get damaged so as to prevent the stalling of the generator

- The under frequency operation of the power transformer is not desirable.

If we implement the PV panel alone will result in the load fluctuation.[6][7] At night we cannot able to access PV panel. It will also results in the voltage fluctuation. So we will incorporate PV panel with battery or other sources or generator. Here we are going to take the system of PV System with thermal generator as shown in figure 15

\subsection{PV Panel Model}

In two area system model we have to create the transfer function model of the each system.[6][7] PV system consists of the PV panel, MPPT, Inverter, Filter. Transfer function model of the each unit has to find out and to create a single transfer function model. The transfer function model of the PV panel can be find out from the equation 1 and 2

Now we have to consider the MPPT. MPPT is done by the BOOST converter. We have to consider the ON state and OFF state mode of operation of[6] the boost converter. It is given by the equations 6,7 .

By combining all these equations we will get the transfer function model of the PV Panel. It is given in the equation 8

$G_{B C}=\frac{-18 s+900}{S^{2}+100 S+50}$

The step input in the PV panel represents the change in irradiation and temperature.

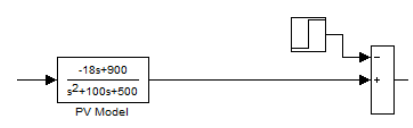

Fig 16 Transfer function model of PV panel

\subsection{Thermal Generator}

The main parts in the power thermal generator are as shown below.

- Generator

- Turbine

- Governor

- Reheater

We have to consider the transfer function model of the each unit to form the model.[6][7] 


$$
\begin{gathered}
\text { Generator } \frac{\mathrm{k}_{G}}{\mathrm{~T}_{G} S+1} \\
\text { Reheater } \frac{k_{R} T_{R} S+1}{T_{G} S+1} \\
\text { Governor } \frac{k_{G o}}{T_{G o} S+1} \\
\text { Turbine } \quad \frac{k_{T}}{T_{T} S+1}
\end{gathered}
$$

The values of different parameters are shown in table below

Table 2 Parameter values

\begin{tabular}{|l|l|}
\hline $\mathrm{k}_{\mathrm{G}}$ & 120 \\
\hline $\mathrm{k}_{\mathrm{R}}$ & .33 \\
\hline $\mathrm{k}_{\mathrm{T}}$ & 1 \\
\hline $\mathrm{k}_{\mathrm{Go}}$ & 1 \\
\hline $\mathrm{T}_{\mathrm{R}}$ & 10 \\
\hline $\mathrm{T}_{\mathrm{T}}$ & .3 \\
\hline $\mathrm{T}_{\mathrm{Go}}$ & .08 \\
\hline $\mathrm{T}_{\mathrm{G}}$ & 20 \\
\hline $\mathrm{a} 12$ & -1 \\
\hline $\mathrm{a} 22$ & -1 \\
\hline $\mathrm{R}$ & .4 \\
\hline $\mathrm{B}$ & .8 \\
\hline
\end{tabular}

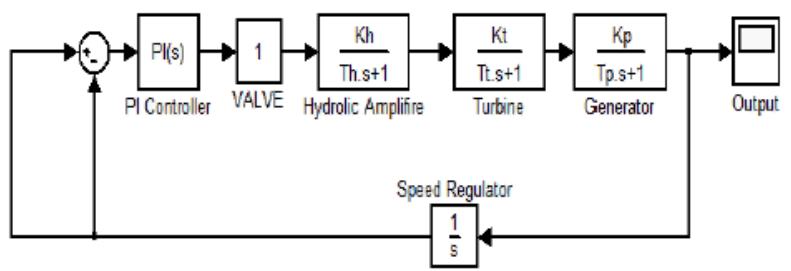

Fig 17 Thermal generator model

\subsection{PI Controller}

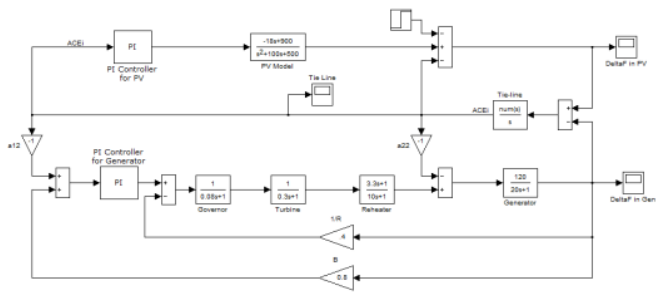

Fig 18 PI Controller model

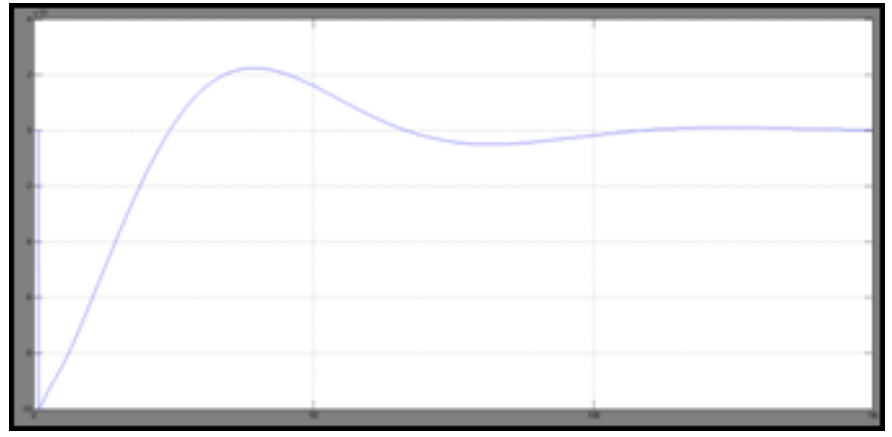

Fig. 19 Output of PV system

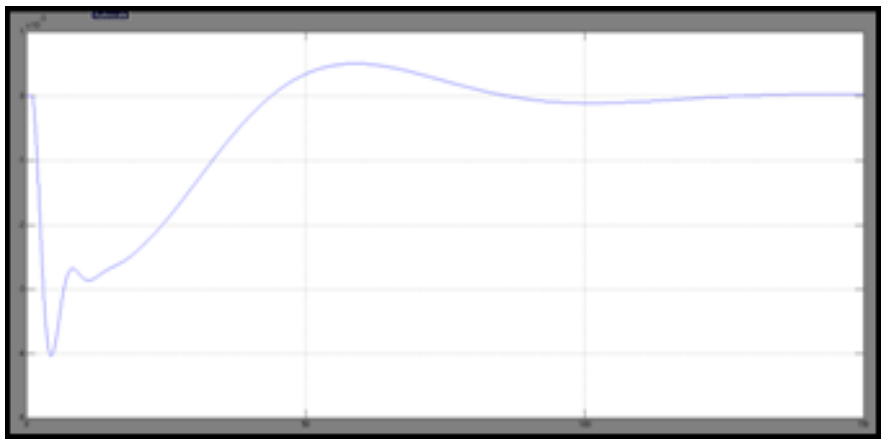

Fig. 20 Output of Thermal generator

\subsection{Fuzzy Logic Controller}

By introducing the fuzzy logic controller we can improve the settling time of the system. Here inputs taken are Area Controlled Error (ACE) and differential ACE. Output taken is the Gain $(\mathrm{G})$.

Inputs and outputs are taken as the membership functions. Each membership function is divided into five fuzzy subsets. The fuzzy subsets are given below.

Positive Big (PB)

Positive Small (PS)

Zero (Z)

Negative Big (NB)

Negative Small (NS)

PI Controller can be converted to fuzzy controller by introducing another block before the transfer function block. Mamdani fuzzy inference is used for the fuzzification. By varying the value of a we will get the required system.
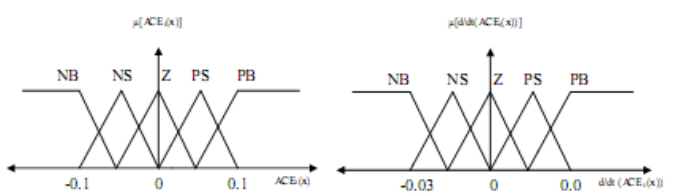

Fig. 21 Membership Function for ACE and Deferential ACE 


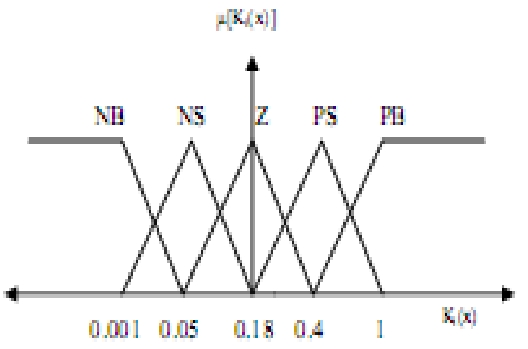

Fig. 22 Membership Function for Gain G

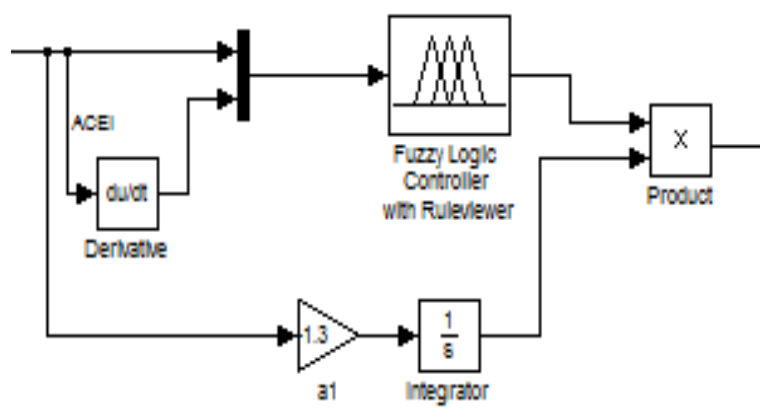

Fig. 23 Block for conversion of PI to fuzzy

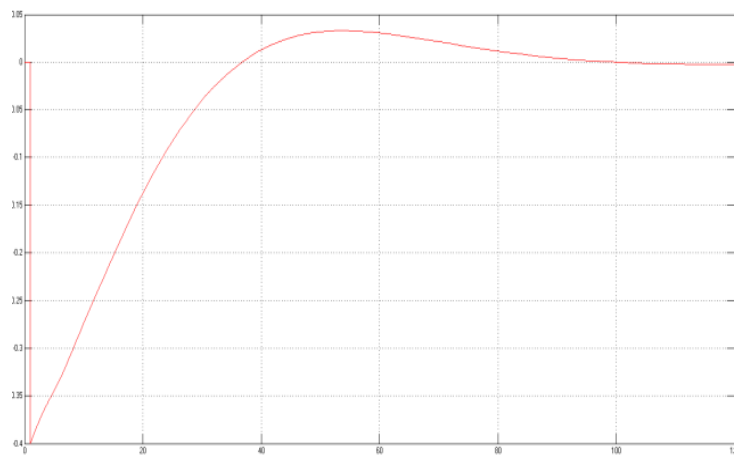

Fig. 24 Output of Fuzzy based PV System

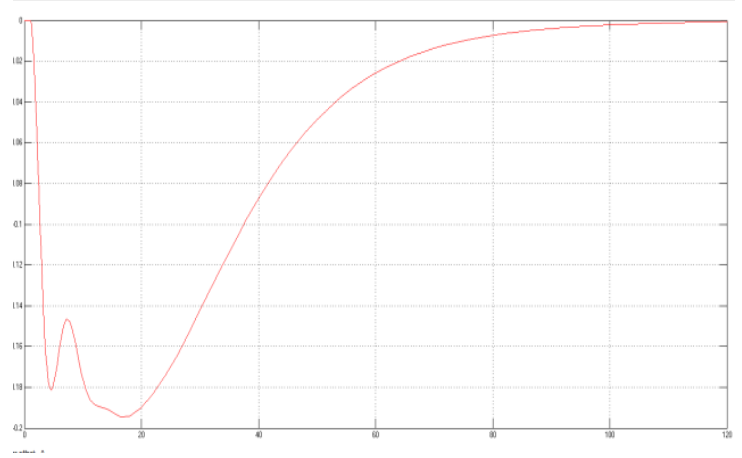

Fig. 24 Output of Fuzzy based Thermal System
Table 2 Fuzzy rule base for LFC

\begin{tabular}{|l|l|l|l|l|l|}
\hline $\begin{array}{l}\text { ACE } i \\
\text { dACEi/dt }\end{array}$ & NB & NS & Z & PS & PB \\
\hline NB & PB & PB & PB & PS & PS \\
\hline NS & PB & PB & PS & PS & PS \\
\hline Z & PS & PS & Z & NS & NS \\
\hline PS & NS & NS & NS & NB & NB \\
\hline PB & NS & NS & NB & NB & NB \\
\hline
\end{tabular}

\section{REFERENCES}

[1] P.Fairley, "Fukushima's positive impact [SpectralLines]," Spectrum, IEEE, vol. 48, no. 5, p. 8, May 2011

[2] G.Spagnuolo, "Renewable energy operation and conversion schemes," IEEE Ind. Electron. Mag. , vol. 4, no. 1, pp. 38-51, Mar. 2010.

[3] D. Sonnenenergie, "Photovoltaic Basics, in Planning and installing photovoltaic systems: A guide forinstallers,architects, and engineers", 2nd ed., Deutsche Gesellschaft für Sonnenenergie, Ed. London: Earthscan Publications Ltd., 2008, ch. 1, pp. 1-62

[4] Bader N. Alajmi, Khaled H. Ahmed, Stephen J. Finney, and Barry W. Williams "Fuzzy-Logic-Control Approach of a Modified Hill-Climbing Method for Maximum Power Point in Microgrid Standalone Photovoltaic System" IEEE TRANSACTIONS ON POWER ELECTRONICS, VOL. 26, NO. 4, APRIL 2011

[5] A. Al Nabulsi, R. Dhaouadi,"Fuzzy Logic Controller Based Perturb and Observe Maximum Power Point Tracking”, International Conference on Renewable Energies and Power Quality (ICREPQ'12) Santiago de Compostela (Spain), 28th to 30th March, 2012

[6] Seyed Ali Jeddi,Seyed Hamidreza Abbasi,Fereydoon Shabaninia, " Load Frequency Control of Two Area Interconnected Power System (Thermal Generator and Solar PV) with PI and FGSPI Controller" The 16th CSI International Symposium on Artificial Intelligence and Signal Processing (AISP 2012)

[7] Manoj Dattaa, Tomonobu Senjyu, Atsushi Yona and Toshihisa Funabashi, "A fuzzy based method for leveling output power fluctuations of photovoltaicthermal hybrid power system" Renewable Energy Volume 36, Issue 6, June 2011, Pages 1693- 1703

[8] Sujit Bhat, Jishan Khatib, Sudheer Chincholi and Ramkrishna Pai, "Design and Analysis of Fuzzy Logic Controller for Load Frequency Control of Power System", International Conference on Computing and 
Control Engineering (ICCCE 2012), 12 \& 13 April, 2012

[9] Emanuel Serban, Helmine Serban, ” A Control Strategy for a Distributed Power Generation Microgrid Application with Voltage and Current Controlled Source Converter" Power Electronics, IEEE Transactions on, 25(12), 2981-2992. doi:10.1109/TPEL.2010.2050006

[10] G.S. Nhivekar, S.S. Nirmale, R.R. Mudholker, "Implementation of fuzzy logic control algorithm in embedded microcomputers for dedicated application" International Journal of Engineering, Science and Technology Vol. 3, No. 4, 2011, pp. 276-283

\section{BIOGRAPHIES}

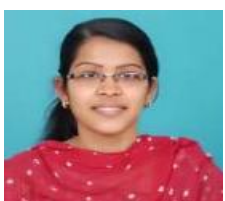

P G Student, Department of Electrical and Electronics Engineering, Vivekanandha college of Engineering for Women, Tiruchengode, Namakkal-637 205, Tamilnadu, India.

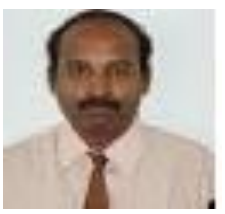

H O D, Department of Electrical and Electronics Engineering, Vivekanandha college of Engineering for Women, Tiruchengode, Namakkal-637 205, Tamilnadu, India. 